\title{
FAKTOR-FAKTOR YANG MEMPENGARUHI PERNIKAHAN DINI REMAJA PUTRI DI DESA SEMETEH MUARA LAKITAN KABUPATEN MUSI RAWAS
}

\author{
Juliana Widyastuti Wahyuningsih \\ Akademi Kebidanan Budi Mulia Palembang
}

\author{
A B S T R A K
}

Informasi Artikel :

Diterima : April 2018

Disetujui : Mei 2018

Dipublikasikan : Juni 2018

"Korespondensi Penulis :

Yulianawidyastuti@ymail.com
Pernikahan dini adalah pernikahan yang dilakukan seorang wanita pada usia 13 - 16 tahun atau pria berusia 17 - 18 tahun (BKKBN,2016). Menurut Laporan Badan Pusat Statistik, 2015 menunjukkan bahwa prevalensi perkawinan usia anak di Indonesia tidak hanya tetap tinggi (dengan lebih dari seperenam anak perempuan menikah sebelum mencapai usia dewasa (usia 18 tahun) atau sekitar 340.000 anak perempuan setiap tahunnya) tetapi prevalensi tersebut juga telah kembali meningkat. Tujuan dari penelitian ini adalah Mengetahui gambaran faktor - Faktor yang mempengaruhi Pernikahan dini Remaja Putri di Desa Semeteh Kecamatan Muara Lakitan Kabupaten Musi Rawas. Penelitian ini dilakukan secara kualitatif di Wilayah Desa Semeteh Muara Lakitan Kabupaten Musi Rawas.dengan jumlah responden 5 orang dari jumlah sampel 11 orang. Hasil penelitian menggambarkan bahwa pernikahan dini dilakukan oleh mereka yang berpendidikan SD atau SLTP, dan berpengetahuan cukup. Pernikahan dini dianggap sesuatu hal yang lazim dan menurunkan tanggung jawab ekonomi orang tua. Selain itu media punya andil terjadinya pernikahan dini. Penelitian ini diharapkan dapat bermanfaat bagi pasangan remaja calon pengantin, mahasiswa dan institusi profesi kebidanan khususnya dalam memberikan pendidikan kesehatan reproduksi remaja terkait dengan masalah pernikahan dini.

Kata Kunci : Pernikahan dini, remaja

\section{ABSTRACK}

Early marriage is a marriage made by a woman at the age of 13-16 years or a man aged 17-18 years (BKKBN, 2016). According to the Central Bureau of Statistics Report, 2015 shows that the prevalence of marriage in Indonesian age is not only high (with more than one-sixth married girls before reaching adulthood (age 18) or about 340,000 girls annually) but the prevalence has also returned increased. The purpose of this study is to know the description of factors - Factors affecting early marriage of Young Women in the Semeteh Village Muara Lakitan Musi Rawas District. This study was conducted qualitatively in Semeteh Village, Muara Lakitan, Musi Rawas District with 5 people as the respondents of the 11 samples. The results of the study indicated that the early marriage was conducted by people who had educated in elementary or junior high schools, and had sufficient knowledge. Early marriage was considered as a usual something and could decrease economic responsibility of their parents. In addition, the media had contributed to the incidence of early marriages. This study is expected to be useful for couples of young people who will get to be married, students and midwifery profession institutions particularly in providing reproductive health education for the adolescences in accordance with the early marriage.

Keyword : Early Marriage, Adolescence 


\section{PENDAHULUAN}

Remaja adalah kelompok masyarakat yang memiliki semangat sehingga bisa dikebungkan untuk hal-hal positif (Surbakti, 2009). Menurut World Health Organization (WHO) remaja merupakan individu yang sedang mengalami masa peralihan yang secara berangsur - angsur mencapai kematangan seksual, mengalami perubahan jiwa dari jiwa kanak - kanak menjadi dewasa, dan mengalami perubahan keadaan ekonomi dari ketergantungan menjadi relatif mandiri (Notoatmodjo, 2007).

Pernikahan dini adalah pernikahan yang dilakukan seorang wanita pada usia 13 - 16 tahun atau pria berusia 17 - 18 tahun (BKKBN,2016). Menurut Laporan Badan Pusat Statistik, 2015 menunjukkan bahwa prevalensi perkawinan usia anak di Indonesia tidak hanya tetap tinggi (dengan lebih dari seperenam anak perempuan menikah sebelum mencapai usia dewasa (usia 18 tahun) atau sekitar 340.000 anak perempuan setiap tahunnya) tetapi prevalensi tersebut juga telah kebuli meningkat. Selanjutnya meskipun perkawinan anak perempuan usia 16 dan 17 tahun masih mengalami peningkatan secara terus-menerus, yang menunjukkan bahwa perlindungan terhadap anakanak perempuan menurun ketika mereka mencapai usia 16 tahun.

Menurut Pohan, 2017. Faktor penyebab pernikahan usia dini yaitu, pemaksaan dari orang tua, pergaulan bebas, rasa keingintahuan tentang dunia seks, faktor ekonomi, faktor lingkungan, dan rendahnya pendidikan. Selain itu faktor penyebab pernikahan usia dini adalah faktor sosial budaya, desakan ekonomi, tingkat pendidikan, sulit mendapat pekerjaan, media massa, agama serta pandangan dan kepercayaan. Asteria Taruliasi Aritonang, Koordinator Gerakan Nasional Kesehatan Ibu dan Anak (GNKIA), Kementerian Kesehatan RI, menyebutkan bahwa resiko yang akan timbul akibat dari pernikahan dini adalah pada rentang usia tersebut dari segi kesiapan secara fisik, salah satunya rongga panggul belum siap menjadi ibu. Lalu, kehamilan pada usia muda pun menyebabkan anemia dan tekanan darah tinggi. Pada kehamilan di usia muda pun kerap dijumpai kelainan letak plasenta atau ari-ari dan lepasnya plasenta sebelum waktunya yang mengakibatkan perdarahan. Ini dapat mengancam jiwa ibu dan bayinya (BKKBN,2016).

Perkawinan remaja selain mencerminkan rendahnya stasus wanita, juga merupakan tradisi sosial yang menopang tingginya tingkat kesuburan. Hal ini menyebabkan periode melahirkan yang dihadapi oleh pengantin remaja relative lebih panjang, disamping resiko persalinan yang semakin tinggi karena secara fisik mereka belum siap melahirkan (Suryati \& Anna, 2009).

Kepala BKKBN Provinsi Sumatera Selatan, Drs. Waspi, dalam global net.News,2017. Mengatakan angka pernikahan dini di Sumatera Selatan masih tinggi, dari 1.000 kelahiran bayi, sebanyak $92,3 \%$ adalah bayi pasangan pernikahan di usia 15 - 19 tahun. Tingginya angka pernikahan dini berpengaruh terhadap faktor kematian ibu hamil dan bayi.

Berdasarkan data Badan Kependudukan dan Keluarga Berencana Nasional (BKKBN) Provinsi Sumatera Selatan, Kabupaten musi Rawas merupakan daerah tertinggi yang melakukan pernikahan usia dini. Sementara Palebung menjadi daerah terendah. Selama tujuh bulan tahun 2017, angka pernikahan dini di Kabupaten Musi Waras (Mura) masih tinggi. Sebanyak 247 remaja dari 1.127 pasangan menikah. Kepala Dinas Pengendalian Penduduk dan Keluarga Berencana (PP-KB) Kabupaten Mura, Jemain mengatakan untuk di Kabupaten Mura selama tujuh bulan tahun 2017 didominasi pasangan remaja sebanyak 247 pasangan. Dari jumlah 1.127 pasangan menikah. Artinya dari jumlah tersebut secara persentase 22 persen dari ideal dibawah 10 persen.

Dari uraian di atas, dapat dilihat bahwa pernikahan di Indonesia yang dilakukan pada usia remaja lebih banyak terjadi di pedesaan. Pernikahan dini mempunyai dampak negatif dipandang dari sudut ilmu kesehatan, baik bagi ibu maupun anak yang dilahirkan. Ditinjau dari sisi sosial, pernikahan dini dapat mengurangi harmonisasi keluarga. Hal ini disebabkan oleh emosi yang masih labil, gejolak darah muda dan cara pikir yang belum matang.

Berdasarkan uraian diatas penulis ingin mengetahui ''Faktor - Faktor yang Mempengaruhi Pernikahan Dini Remaja Putri Desa Semeteh Kecamatan Muara Lakitan Kabupaten Musi Rawas'.

\section{METODE PENELITIAN}

Penelitian ini menggunakan metode penelitian kualitatif. Metode Penelitian kualitatif merupakan penelitian yang mengkaji kualitatif perspektif partisipan dengan strategi-strategi yang yang bersifat interaktif dan fleksibel. Penelitian kualitatif ditujukan untuk memahami fenomenafenomena sosial dari sudut pandang partisipan. Dengan demikian arti dari kualitatif adalah penelitian yang digunakan untuk meneliti pada kondisi objek alamiah dimana peneliti merupakan instrumen kunci (Sugiyono, 2005). 
Adapun populasi dalam penelitian ini adalah Pasangan Suami Istri yang menikah di Usiah Kurang dari 20 tahun yang berjumlah 11 orang.

Penelitian ini menggunakan tehnik pengambilan sampel dengan menggunakan tehnik snowball sampling. Snowball Sampling adalah metode sampling di mana sampel di peroleh melalui proses bergulir dari satu responden ke responden yang lain.

Analisis data dalam penelitian kualitatif, dilakukan pada saat pengumpulan data berlangsung, dan setelah selesai pengumpulan data dalam periode tertentu. Pada saat wawancara, peneliti sudah melakukan analisis terhadap jawaban yang diwawancarai. Bila jawaban yang diwawancarai setelah dianalisis terasa belum memuaskan, maka peneliti akan melanjutkan pertanyaan lagi, sampai tahap tertentu, diperoleh data yang dianggap kredibel.

\section{HASIL PENELITIAN}

1. Karakteristik Responden

\section{Tabel 1 Karakteristik Responden}

\begin{tabular}{ccccc}
\hline $\begin{array}{c}\text { Ko } \\
\text { de }\end{array}$ & Nama & Umur & $\begin{array}{c}\text { Usia saat } \\
\text { menikah }\end{array}$ & Alamat \\
\hline R1 & Ny. N & 18 tahun & 17 tahun & Ds. Semeteh \\
R2 & Ny. W & 17 tahun & 16 tahun & Ds. Semeteh \\
R3 & Ny. S & 16 tahun & 15 tahun & Ds. Semeteh \\
R4 & Ny. T & 18 tahun & 16 tahun & Ds. Semeteh \\
R5 & Ny. R & 19 tahun & 17 tahun & Ds. Semeteh \\
\hline
\end{tabular}

\section{Pelaksanaan Penelitian}

Penelitian ini lebih difokuskan pada hasil perolehan data yang bersifat kualitatif, sehingga beberapa gaburan serta kesimpulan dapat dihasilkan untuk mengetahui faktor - faktor yang memepengaruhi terjadinya pernikahan dini dengan pendekatan wawancara yang mendalam yang dilaksanakan selama bulan Maret 2018. Wawancara dilaksanakan pada masing - masing responden secara terpisah. Responden dengan jumlah 5 orang, dan keseluruhan responden adalah perempuan. Dari data wawancara didapatkan hasil yang bervariasi sesuai pendapat masing - masing responden.

Hasil dari wawancara ditulis selengkap lengkapnya sesuai dengan hasil wawancara dari rekaman dan dari catatan. Kemudian data yang telah ditulis diamati berkali - kali selanjutnya menentukan kategori serta memberi nomor pada setiap kategori.

\section{Penyajian Data}

a. Pernyataan responden tentang pengetahuan

Tabel 2 Pernyataan responden mengenai pengetahuan tentang pernikahan

\begin{tabular}{|c|c|c|}
\hline No & Kata Kunci & Kategori \\
\hline 1. & $\begin{array}{l}\text { Responden belum } \\
\text { ada yang tinggal di } \\
\text { rumah sendiri }\end{array}$ & $\begin{array}{l}\text { Tempat tinggal } \\
\text { responden } \\
\text { setelah menikah }\end{array}$ \\
\hline 2. & $\begin{array}{l}\text { Responden menikah } \\
\text { saat berumur } 15 \\
\text { tahun, } 16 \text { tahun, } 17 \\
\text { tahun }\end{array}$ & $\begin{array}{l}\text { Usia saat } \\
\text { responden } \\
\text { menikah }\end{array}$ \\
\hline 3. & 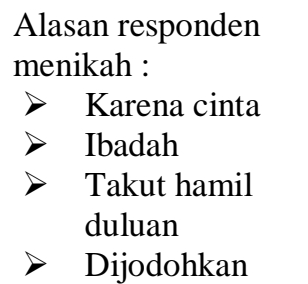 & $\begin{array}{l}\text { Alasan } \\
\text { responden } \\
\text { menikah }\end{array}$ \\
\hline 4. & $\begin{array}{l}\text { Tujuan pernikahan } \\
\text { adalah ibadah. } \\
\text { Mempunyai anak, } \\
\text { menyenangkan } \\
\text { orang tua, agar tidak } \\
\text { hamil diluar nikah }\end{array}$ & $\begin{array}{l}\text { Tujuan } \\
\text { pernikahan }\end{array}$ \\
\hline 5. & $\begin{array}{l}\text { Mencatatkan } \\
\text { pernikahan di KUA }\end{array}$ & $\begin{array}{l}\text { Tempat } \\
\text { mencatatkan } \\
\text { pernikahan }\end{array}$ \\
\hline 6. & $\begin{array}{l}\text { Syarat pernikahan } \\
\text { adalah calon } \\
\text { pengantinya, orang } \\
\text { tua,foto kopi akte, } \\
\text { foto kopi ijasah, } \\
\text { penghulu, wali } \\
\text { nikah, saksi, mas } \\
\text { kawin. }\end{array}$ & $\begin{array}{l}\text { Syarat } \\
\text { pernikahan }\end{array}$ \\
\hline 7. & $\begin{array}{l}\text { Pernikahan dini } \\
\text { adalah menikah di } \\
\text { bawah usia } 20 \\
\text { tahun, menikah di } \\
\text { usia dini }\end{array}$ & $\begin{array}{l}\text { Pengertian } \\
\text { pernikahan dini } \\
\text { menurut } \\
\text { responden }\end{array}$ \\
\hline 8. & $\begin{array}{l}\text { Menikah di bawah } \\
\text { usia } 20 \text { tahun }\end{array}$ & $\begin{array}{l}\text { Usia pernikahan } \\
\text { dini menurut } \\
\text { responden }\end{array}$ \\
\hline 9. & $\begin{array}{l}\text { Menikah diusia } 21 \\
\text { tahun, } 23 \text { tahun, } 24 \\
\text { tahun }\end{array}$ & $\begin{array}{l}\text { Usia ideal untuk } \\
\text { menikah } \\
\text { menurut } \\
\text { respoden }\end{array}$ \\
\hline 10. & $\begin{array}{l}\text { Resiko yang muncul } \\
\text { dari pernikahan dini } \\
\text { adalah perceraian, } \\
\text { tidak bahagia, sering } \\
\text { berantem sama } \\
\text { suami, cek cok }\end{array}$ & $\begin{array}{l}\text { Resiko } \\
\text { terjadinya } \\
\text { pernikahan dini }\end{array}$ \\
\hline 11. & $\begin{array}{l}\text { Upaya untuk } \\
\text { mencegah } \\
\text { pernikahan dini } \\
\text { adalah sekolah lagi } \\
\text { dan kerja }\end{array}$ & $\begin{array}{l}\text { Upaya untuk } \\
\text { mencegah } \\
\text { pernikahan dini }\end{array}$ \\
\hline
\end{tabular}


Hasil kesimpulan pernyataan tentang pengetahuan yaitu bahwa tiap - tiap responden memiliki persepsi masing - masing mengenai pernikahan dini, juga pengetahuan tentang resiko yang mungkin muncul bila terjadi pernikahan dini, serta upaya yang dapat dilakukan untuk mencegah terjadinya pernikahan dini. Namun dari pernyataan yang diutarakan oleh responden tentang tujuan menikah, yaitu agar tidak terjadi kehamilan diluar nikah, hal ini menunjukkan sisi baik dari diambilnya keputusan untuk menikah, juga adanya pernyataan yang menyatakan bahwa mereka menikah karena ingin mebuntu orang tua, jadi bukan semata- mata untuk kepentingan pribadi responden.

Dalam hal ini pengetahuan yang dimiliki responden merupakan faktor yang mempengaruhi terjadinya pernikahan dini.

b. Pernyataan responden tentang pendidikan Pernyataan responden mengenai pendidikan dapat di uraikan melalui jawaban dalam tabel 3 di bawah

Tabel 3 Tingkat Pendidikan

\begin{tabular}{|c|c|c|}
\hline No & Kata Kunci & Kategori \\
\hline 1. & $\begin{array}{l}\text { Pendidikan terakhir yang } \\
\text { ditempuh lulus SD dan SMP }\end{array}$ & Pendidikan dasar \\
\hline 2. & $\begin{array}{l}\text { Lulus tahun 2006, 2007, 2009, } \\
2010\end{array}$ & $\begin{array}{l}\text { Tahun kelulusan } \\
\text { responden }\end{array}$ \\
\hline 3. & $\begin{array}{l}\text { Perolehan informasi kesehatan } \\
\text { Bagi responden yang } \\
\text { hanya sekolah dasar tidak } \\
\text { mendapatkan informasi } \\
\text { tentang kesehatan } \\
>\quad \text { Bagi yang sekolah sampai } \\
\text { SMP mendapatkan } \\
\text { pendidikan kesehatan dari } \\
\text { pelajaran IPA }\end{array}$ & $\begin{array}{l}\text { Sumber informasi } \\
\text { formal tentang } \\
\text { kesehatan }\end{array}$ \\
\hline 4. & $\begin{array}{l}\text { Perolehan informasi pernikahan } \\
>\quad \text { Responden yang sekolah } \\
\text { dasar tidak mendapatkan } \\
\text { informasi tentang } \\
\text { pernikahan dini } \\
>\quad \text { Responden yang sekolah } \\
\text { sampai SMP, informasinya } \\
\text { di dapat dari pelajaran } \\
\text { agama }\end{array}$ & $\begin{array}{l}\text { Sumber informasi } \\
\text { formal tentang } \\
\text { pernikahan }\end{array}$ \\
\hline 5. & $\begin{array}{l}\text { Informasi dari orang tua, teman } \\
\text { yang sudah menikah }\end{array}$ & $\begin{array}{l}\text { Sumber informasi } \\
\text { mengenai } \\
\text { pernikahan dari } \\
\text { luar sekolah }\end{array}$ \\
\hline
\end{tabular}

Hasil kesimpulan mengenai pernyataan tentang pendidikan diperoleh bahwa responden rata - rata hanya lulus SD, ada sebagian yang sempat lulus SMP. Responden belum mengetahui mengenai pernikahan, informasi tentang pernikahan yang mereka ketahui dari orang tua karena lulusan SD dan SMP belum mengetahui tentang pernikahan, jadi pendidikan yang telah ditempuh dapat menjadi faktor yang mempengaruhi pernikahan dini, karena rendahnya tingkat pendidikan juga mempengaruhi banyak sedikitnya informasi yang dimiliki.

c. Pernyataan mengenai tingkat sosial ekonomi Pernyataan tentang tingkat sosial ekonomi dapat dilihat pada kotak dibawah ini

Tabel 4 Pernyataan tentang tingkat sosial ekonomi

1. Apakah sebelum anda menikah dahulu anda bekerja? Apa?

R1 : Tidak

R2 : Ya, Pelayan di toko bangunan

R3 : Tidak

R4 : Ya di Surabaya

R5 : Pembantu rumah tangga

2. Kalo boleh tahu berapa pendapatan yang anda terima dulu setiap bulan ketika bekerja?

R1 : -

$\mathrm{R} 2: \pm \mathrm{Rp} 1000.000,-$

R3 : -

$\mathrm{R} 4: \pm \mathrm{Rp} 700.000,-$

R5 : \pm Rp 200.000,-

3. Apakah pendapatan yang telah anda terima dulu itu sudah mencukupi untuk dapat memenuhi kebutuhan anda sendiri?

R1 : -

R2 : cukup

R3 : -

R4 : Cukup

R5 : Cukup

4. Apakah pendapatan yang anda terima itu anda pergunakan untuk mebuntu orang tua dirumah?

R1 : -

R2 : Ya... kadang - kadang ngirim orang tua

R3 :-

R4 :Ya... kadang - kadang ngirim

R5 : Ya...

5. Setelah menikah apakah anda bekerja?

R1 : Tidak

R2 : Tidak

R3 : Tidak

R4 : Tidak

R5 : Tidak bu... tidak boleh sama suami

6. Bagaimana dengan suami, apa pekerjaan suami anda? 
R1 : Bekerja sebagai pedagang

R2 : Bekerja sebagai CS di Palembang

R3 : Serabutan

R4 : Supir angkot

R5 : Kerja di bengkel

7. Berapa pendapatan yang anda terima bersama suami dalam satu bulan?

$\mathrm{R} 1: \pm \mathrm{Rp} 250.000,-$

$\mathrm{R} 2: \pm \operatorname{Rp} 900.000,-$

$\mathrm{R} 3$ : Ga... tentu Mb.

$\mathrm{R} 4: \pm \mathrm{Rp} 30.000,-/$ hari

R5 : \pm Rp 500.000,-

8. Cukupkah pendapatan itu di pergunakan untuk kebutuhan sehari hari anda sekeluarga?

R1 : Cukup

R2 : Cukup

R3 : Di cukup - cukupinlah

R4 : Cukup

R5 : Cukup

9. Apakah anda juga mebuntu memenuhi kebutuhan orang tua anda dan mertua? R1 : Kadang - kadang kalau ada rejeki tabuhan

R2 : Kadang - kadang

R3 : Kadang - kadang tapi biasanya saya yang di kasih

R4 : Kadang - kadang ngasih

R5 :Kadang - kadang kalua ada rejeki tabuhan

Kesimpulan dari hasil wawancara dengan responden tentang tingkat sosial ekonomi adalah tiap - tiap responden memiliki pendapatan yang berbeda - beda, namun hampir keseluruhan responden menyatakan cukup dalam pemenuhan kebutuhannya sehari - hari selama sebelum menikah dan setelah menikah responden menganggap dengan menikah kebutuhan makan dan sebagainya semakin mencukupi. Dengan ini tingkat sosial ekonomi keluarga dapat dijadikan faktor yang mempengaruhi terjadinya pernikahan dini.

\section{Hasil Wawancara Sumber Lain}

Triangulasi data adalah teknik pemeriksaan keabsahan data yang memanfaatkan sesuatu yang lain di luar data itu untuk keperluan pengecekan/sebagian pebunding terhadap data itu (Moleong, 2007).

Teknik Triangulasi yang dipakai oleh peneliti adalah triangulasi dengan sumber. Triangulasi sumber yang digunakan pada penelitian ini yaitu data hasil pengamatan atau observasi yang dilakukan oleh peneliti ketika melakukan wawancara mendalam dengan responden dan mebundingkan informasi data dengan nara sumber lain.

Hasil wawancara sumber lain yang diperoleh adalah dari orang tua responden yang melakukan pernikahan dini didapatkan banyak kesamaan dengan hasil wawancara kepada responden, dengan demikian maka bahwa data tersebut adalah valid.

\section{Penyajian hasil wawancara dengan sumber lain}

1.Karakteristik sumber lain

Tabel 5 Karakteristik Sumber Lain

\begin{tabular}{clccc}
\hline Kode & Nama & Umur & $\begin{array}{c}\text { Hubungan dengan } \\
\text { responden }\end{array}$ & Alamat \\
\hline Ortu1 & Ibu W & 39 tahun & Orang tua kandung & Desa Semeteh \\
Ortu2 & Ibu N & 37 tahun & Orang tua kandung & Desa Semeteh \\
Ortu3 & Ibu S & 43 tahun & Orang tua kandung & Desa Semeteh \\
Ortu4 & Ibu T & 45 tahun & Orang tua kandung & Desa Semeteh \\
Ortu5 & Ibu W & 35 tahun & Orang tua kandung & Desa Semeteh \\
\hline
\end{tabular}

2. Penyajian Hasil

a. Berapa usia anak Ibu dulu menikah?

Ortu1 : Kira - kira 17 tahun

Ortu2: 16 tahun

Ortu3 : 15 tahun

Ortu $4: 16$ tahun

Ortu5 : 17 tahun

b. Apa alasan anak Ibu menikah?

Ortu1 : Sudah terlanjur cinta

Ortu2 : Takut hamil duluan bu

Ortu3 : Saya jodohkan bu...

Ortu4 : Takut bu...

Ortu5 : Saya jodohkan Bu...

c. Apa pendidikan terakhir anak Ibu?

Lulus tahun berapa?

Ortu1 : SMP, 2010

Ortu2 : SMP, 2009

Ortu3 : SD, 2008

Ortu4 : SD, 2006

Ortu5 : SD, 2007

d. Menurut Ibu, bagaimana pendapat masyarakat tentang pernikahan dini?

Ortu1 : Biasa bu

Ortu 2 : dak apo-apo bu, sudah idak sekolah lagi

Ortu 3 : Biasa lah Bu...

Ortu4 : Biasa Bu... kan sudah idak sekolah lagi

Ortu5 : Ya... biasa Bu...

e. Saat anak Ibu sudah menstruasi, apa menurut anda dia sudah pantas untuk menikah?

Ortu1 : Sudah Bu

Ortu2 : Sudah... soalnya sudah bisa punya anak 
Ortu3 : Sudah boleh Bu

Ortu4 : Sudah bu, kan sudah dewasa

Ortu5 : Sudah Bu... sudah dewasa

f. Kalau anak laki - laki, kapan pantas menikah?

Ortu1 : Kalau sudah kerja

Ortu2 : Kalau sudah bisa cari uang

Ortu3 : Kalau sudah mapan

Ortu4 : Kalau sudah kerja

Ortu5 : Kalau sudah kerja

g. Apa sebelum menikah anak Ibu kerja?

Apa?

Ortu1 : Tidak

Ortu2 : Kerja di toko bangunan

Ortu3 : Kerja Bu...

Ortu4 : Tidak Bu...

Ortu5 : Kerja jadi pembantu

h. Apakah dengan pendapatannya anak Ibu mebuntu keluarga?

Ortu1 : -

Ortu2 : Ya.. bantu setiap bulan ngirim saya

Ortu3 : Ya... kadang - kadang ngirim

Ortu4 : -

Ortu5 : Ngirim kadang - kadang

i. Setelah menikah apakah anak Ibu tetap kerja?

Ortu1 : Tidak

Ortu2 :Tidak

Ortu3 : Tidak

Ortu4 : Tidak

Ortu5 : Tidak

j. Bagaimana dengan suaminya apa pekerjaannya?

Ortu1 : Dagang Bu...

Ortu2 : Kerja jadi OS di Surabaya

Ortu3 : Kerjanya serabutan

Ortu4 : Kerja jadi supir angkot

Ortu5 : Kerja di bengkel

k. Menurut Ibu, cukupkah pendapatan yang mereka terima untuk memenuhi kebutuhan sehari - hari mereka?

Ortul : Ya... Cukup lah

Ortu2 : Cukup

Ortu3 : Cukup

Ortu4 : Ya... di cukup - cukupi

Ortu5 : Cukup

1. Apakah mereka mebuntu Ibu?

Ortul : Ya... kadang - kadang Bu

Ortu2 ; Kadang - kadang bantu

Ortu3 : Kadang - kadang bantu

Ortu4 : Bantu mudah-mudahan ada

rezeki tambahan

Ortu5: Kadang - kadang bantu

m. Sekarang mereka tinggal dimana?

Ortu1 : Tinggal sama saya $\mathrm{Bu}$
Ortu2 : Tinggal bareng saya

Ortu3 : Kadang sama saya kadang sama mertuanya

Ortu4 : Sama mertuanya

Ortu5 : Sama mertuanya

\section{PEMBAHASAN}

1. Pengetahuan

Dari hasil penelitian menunjukkan bahwa pengetahuan responden berbeda - beda mengenai pernikahan dini. Namun perbedaan pengetahuaan tersebut tidak memberikan pengaruh apa - apa terhadap terjadinya pernikahan dini, hal ini dibuktikan dengan adanya responden yang mengetahui dampak yang mungkin muncul bila terjadi pernikahan dini, namun tetap saja responden tersebut melakukan pernikahn dini. Juga mengenai upaya - upaya pencegahan pernikahan dini, keseluruhan responden mengetahui upaya apa saja yang sekiranya dapat dilakukan untuk menghindari pernikahan dini, namun pada kenyataannya pernikahan dini tetap terjadi.

Hal pertama yang paling mendasar adalah mengenai pengertian dan tujuan pernikahan, keseluruhan responden menyatakan bahwa menikah adalah menjadi suami istri secara resmi, yang bertujuan untuk mempunyai anak, ibadah, dan menghindari kehamilan di luar nikah, selain itu ada juga responden yang menyatakan bahwa menikah itu untuk menyenangkan orang tua. Menurut UU Perkawinan no 1 Tahun 1974 menyatakan bahwa pernikahan adalah ikatan lahir batin antara seorang pria dengan seorang wanita sebagai suami istri dengan tujuan membentuk keluarga ( rumah tangga ) yang bahagia dan kekal berdasarkan Ketuhanan Yang Maha Esa. Dalam kalimat tersebut dapat diartikan sebagai suami istri adalah sama dengan menjadi suami istri, pengertian tentang membentuk suatu keluarga dapat disarikan dari tujuan menikah untuk mempunyai anak. Berdasarkan Ketuhanan Yang Maha Esa dapat disimpulkan dari tujuan menikah yaitu untuk ibadah dan menghindari kehamilan diluar nikah, dimana ibadah merupakan suatu hubungan _..ngan Tuhan, dan menghindari kehamilan di luar nikah berarti menghindari zina yang jelas sangat bertentangan dengan Tuhan. Jadi dalam hal ini responden memiliki pengetahuan yang cukup mengenai pengertian dan tujuan pernikahan. Namun untuk pernikahan dini sendiri, responden menyatakan bahwa pernikahan dini adalah menikah di usia muda 
dan saat diminta menyebutkan batasan umur, mereka menyatakan umur kurang dari 20 Tahun, ini sesuai dengan UU Perkawinan no 1 Tahun 1974 yang menyatakan pernikahan dini adalah saat usia kurang dari 16 Tahun bagi perempuan dan 18 Tahun bagi laki - laki (Godam, 2008).

Dari hasil penelitian terhadap responden sebanyak 5 orang mereka mengatakan resiko dari pernikahan dini adalah perceraian, tidak bahagia, cek - cok dan sering berantem dengan suami. Hal ini sesuai dengan teori yang dikemukakan oleh Suryati dan Anna (2009) bahwa dampak yang terjadi dari pernikahan dini diantaranya perceraian, karena kawin cerai biasanya terjadi pada pasangan yang umurnya pada waktu kawin relative masih muda. Sedangkan upaya yang harus dilakukan menurut Suryati dan Anna (2009) adalah menetapkan usia perkawinan yang baik di atas usia 20 Tahun dan melarang perkawinan pada umur kurang dari 20 Tahun agar wanita terhindar dari resiko tingginya angka kesakitan dan kematian saat hamil dan melahirkan serta meningkatkan pendidikan pada wanita dengan sekolah yang tinggi. Wanita saat kini diharapkan dapat lebih berkreasi dan berkarya dalam kehidupannya agar kelak mapan dalam pendidikan.

Berdasarkan hasil wawancara mengenai tempat dimana mencatatkan pernikahan dan syarat apa saja yang diperlukan untuk menikah, keseluruhan responden menyatakan mencatatkan di KUA. Sedangkan untuk syarat menikah responden dapat menyebutkan syarat yang paling mendasar yaitu calon pengantinnya, orang tua, foto kopi ijasah pendidikan terakhir, penghulu, wali nikah, saksi dan mas kawin.

Mengenai usia ideal untuk menikah, responden menyatakan bahwa menikah ideal adalah usia 21 Tahun, 23 Tahun dan 24 Tahun atau dapat disimpulkan saat usia lebih dari 16 Tahun, ini sudah sesuai dengan UU perkawinan yang menyatakan usia menikah adalah 16 Tahun bagi wanita dan 18 Tahun bagi laki laki, namun pada kenyataannya responden mengaku bahwa mereka menikah saat berusia 15 Tahun, 16 Tahun dan 17 Tahun. Hal ini jelas menunjukkan bahwa sebenarnya mereka mengetahui usia ideal untuk menikah namun karena alasan tertentu mereka jadi menikah di usia yang masih sangat belia. Alasan yang mereka utarakan pun sangat beragam, mulai dari yang paling polos mengatasnamakan cinta, meringankan beban ekonomi orang tua dan karena takut hamil duluan. Alasan - alasan ini jelas sangat logis bila dihubungkan dengan kondisi lingkungan yang ada, dimana mereka hanya mendapatkan informasi tentang pernikahan dari televisi dan orang tua, sedangkan usia belasan adalah usia yang memerlukan bimbingan dalam pemahaman suatu masalah, agar tidak terjadi kesalahan pengertian.

Orang tua sebagai pendidik langsung kedewasaan anak memiliki peranan penting dalam penerimaan pengetahuan untuk si anak. Pemberian informasi terkadang sangat kurang dan tidak tepat waktu, misalnya anak baru diberi tahu masalah pernikahan setelah si anak setuju untuk menikah, padahal sebaiknya informasi mengenai pernikahan diberikan pada saat anak belum memberikan keputusan untuk mau atau tidak dinikahkan, sehingga anak dapat memikirkan masalah pernikahan tersebut secara matang. Selain itu kendala yang muncul adalah anggapan masyarakat bahwa menikah itu disamakan dengan melakukan hubunan seksual dimana para orang tua menganggap bahwa membicarakan masalah seksual adalah tabu. Oleh sebab itu pengetahuan yang dimiliki tentang kesehatan dan pernikahan sangatlah minimal atau bahkan tidak ada ( Puspitasari, 2006).

Oleh karena sangat sedikitnya sumber informasi maka pengetahuan yang diperoleh pun sangat sedikit, padahal masa remaja pada saat berusai belasan adalah masa yang sangat rentan terjadi kesalahpahaman atau salah persepsi mengenai banyak hal. Salah satu contoh yang dapat diambil adalah pengetahuan tentang kesehatan reproduksi remaja. Remaja bisa mendapatkan informasi mengenai kesehatan reproduksi remaja. Remaja bisa mendapatkan informasi mengenai kesehatan reproduksi secara luas, apalagi pada jaman sekarang dimana media massa sudah sangat beragam, namun hal ini perlu diimbangi dengan pemberian pengertian yang tepat mengenai kesehatan reproduksi remaja, sehingga kesalahan akan informasi dapat dihindari. Bila remaja mendapatkan informasi saja maka jelas pengetahuan yang dimiliki juga akan menjadi salah. Kesalahan dalam pemahaman mengenai kesehatan reproduksi remaja misalnya adanya anggapan baahwa gadis yang sudah menstruasi berarti sudah bisa punya anak, tapi sebenarnya dalam hal ini perlu ditambahkan pengetahuan tentang masa reproduksi sehat yaitu saat wanita berusia 20 - 35 tahun, jadi walaupun anak perempuan sudah menstruasi bukan berarti sudah boleh hamil. 
Kesalahan - kesalahan pengertian inilah yang menyebabkan kesalahan pengetahuan yang dimiliki oleh remaja, jadi secara tidak langsung kurangnya pengetahuan yang dimiliki oleh remaja merupakan faktor yang mempengaruhi terjadinya pernikahan dini.

Menurut Irmawati (2007) pengetahuan adalah informasi atau maklumat yang diketahui atau disadari oleh seseorang. Pengetahuan muncul ketika seseorang menggunakan akal budinya untuk mengenali benda atau kejadian tertentu yang belum pernah dilihat atau dirasakan sebelumnya. Pengetahuan seseorang tentang pernikahan dipengaruhi oleh tingkat pendidikan, serta informasi yang diperoleh dari media massa.

2. Pendidikan

Berdasarkan hasil wawancara mendalam dengan 5 responden mengenai tingkat pendidikan yang dimiliki responden didapatkan bahwa keseluruhan responden paling banyak hanya lulus SD ada sebagian yang lulus SMP.

Pendidikan memberikan pengaruh yang cukup besar dalam kejadian pernikahan dini, karena dengan pendidikan yang hanya sampai pada tingkat pendidikan dasar menyebabkan kurang atau bahkan tidak didapatkannya informasi tentang perkawinan (Puspitasari, 2006).

Sebagian responden menyatakan bahwa hanya mampu menyelesaikan pendidikan sampai tingkat dasar (SD), sedangkan dalam pendidikan dasar tidak diajarkan mengenai kesehatan apalagi kesehatan reproduksi remaja sehingga responden tidak tahu apa itu kesehatan reproduksi remaja yang menyebabkan responden juga tidak mengetahui perihal pernikahan. Selama menempuh pendidikan dasar sama sekali tidak pernah di singgung masalah tentang pernikahan, hal ini yang dapat menyebabkan ketidaktahuan remaja tentang waktu yang tepat untuk menikah.

Sama halnya dengan responden yang mampu melanjutkan ke tingkat SLTP, walaupun tingkat pendidikannya lebih tinggi namun informasi yang didapatkan mengenai kesehatan juga sangat minim, ada responden yang menyatakan bahwa mendapatkan informasi tentang kesehatan saat pelajaran IPA, namun juga tidak banyak, hanya secara umum, bukan lebih khusus kearah kesehatan reproduksi remaja.

Jadi dapat disimpulkan bahwa tingkat pendidikan responden merupakan faktor yang mempengaruhi terjadinya pernikahan dini, karena semakin rendah pendidikan yang pernah ditempuh oleh seseorang maka makin sedikit pula pengetahuan yang dimiliki, dalam hal ini lebih di khususkan mengenai pernikahan jadi keseluruhan responden menyatakan bahwa mereka memperoleh informasi tentang pernikahan dari luar sekolah, yaitu dari orang tua yang terkadang membicarakan masalah pernikahan atau bahkan perceraian, namun kebanyakan dari televisi melalui acara gossip artis atau film - film yang bercerita tentang pernikahan.

Menurut Suparyanto (2011) makin rendah tingkat pendidikan, makin mendorong cepatnya perkawinan usia muda. Peran pendidikan anak - anak sangat mempunyai peran yang besar. Jika seorang anak putus sekolah pada usia wajib sekolah, kemudian mereka akan mengisi waktu dengan bekerja, dengan bekerja anak tersebut sudah merasa cukup mandiri, sehingga merasa mampu untuk menghidupi diri sendiri. Hal yang sama juga jika anak yang putus sekolah tersebut menganggur. Dalam kekosongan waktu tanpa pekerjaan membuat mereka akhirnya melakukan hal - hal yang tidak produktif. Salah satunya adalah menjalin hubungan dengan lawan jenis, yang jika diluar control membuat kehamilan di luar nikah.

Rendahnya tingkat pendidikan maupun pengetahuan orang tua, anak dan masyarakat, menyebabkan adanya kecenderungan mengawinkan anaknya yang masih dibawah umur. Semakin tinggi tingkat pendidikan seseorang, makin mudah menerima informasi, sehingga makin banyak pula pengetahuan yang baru dimiliki. Sebaliknya, pendidikan yang kurang akan menghambat perkembangan sikap seseorang terhadap pengetahuan yang dimiliki tentang pernikahan (Suparyanto, 2011).

Media massa saat ini sangat beragam, bukan hanya sekedar televise atau radio, namun juga internet yang sudah bisa diakses bahkan sampai kepedesaan yang membuat informasi makin mudah didapatkan. Hal ini justru memancing anak dan remaja untuk mengadopsi kebiasaan - kebiasaan yang tidak baik seperti merokok, minum - minuman beralkohol, penyalahgunaan obat terlarang, perkelahian antar remaja atau tawuran, yang pada akhirnya kebiasaan itu mengantarkan pada lebih cepatnya usia kematangan seksual sehingga dapat menyebabkan munculnya kebiasaan berperilaku seksual yang beresiko tinggi yang akhirnya menjadi faktor yang mempengaruhi terjadinya pernikahan dini. Perilaku seksual resiko tinggi ini misalnya melakukan hubungan seksual 
sebelum menikah, pada kejadian seperti ini pihak perempuan adalah pihak yang paling dirugikan, maka kemudian muncul tuntutan untuk menikahkan anak perempuan tanpa mempertimbangkan usia saat meereka menikah (Viny, 2011).

3. Tingkat sosial ekonomi

Menurut hasil wawancara responden, sosial ekonomi yang dimiliki keluarga adalah berbeda - beda dan kebanyakan masih banyak yang kurang. Hal ini jelas memberikan pengaruh terhadap pernikahan dini. Keadaan ekonomi di pedesaan yang membuat anak yang berusia belasan lebih memilih tidak melanjutkan sekolah, jika anak tidak melanjutkan sekolah maka jelas dia akan memilih untuk bekerja. Hal ini yang dapat memberikan pengaruh terhadap terjadinya pernikahan, karena anak menganggap dirinya sudah mampu untuk menghasilkan uang. Secara tidak langsung anak juga akan merasa bahwa dia sudah pantas untuk menikah.

Selain itu anggapan bahwa bekerja itu lebih enak daripada bersekolah, karena sudah tidak berfikir mengenai tugas - tugas yang berhubungan dengan pendidikan, yang menjadi pertimbangan adalah bekerja dan memperoleh panghasilan, otomatis beban hidup akan menjadi lebih ringan dari pada saat masih sekolah.

Orang tua juga memberikan pengaruh yang cukup besar dalam hal ini, misalnya orang tua yang merasa sudah tidak mampu untuk membianyai sekolah anaknya pasti akan meminta si anak untuk keluar dari sekolah dan bekerja saja, walaupun mungkin pekerjaan yang dilakukan bersifat kasar atau seadanya, karena kita juga tahu dengan pendidikan yang rendah pasti akan sulit untuk mendapatkan pekerjaan seperti yang diinginkan.

Masyarakat beranggapan dengan menikahkan anaknya dapat meningkatkan pendapatan keluarga karena si anak dan menantu akan membantu bekerja atau malah mengurangi beban orang tua karena setelah menikah secara tidak langsung tanggung jawab ekonomi berpindah dari orang tua ke suaminya (Suparyanto, 2011).

Anggapan masyarakat yang seperti ini jelas akan semakin meningkatkan kejadian pernikahan dini di kalangan masyarakat kita, karena dapat menjadi faktor yang mempengaruhi terjadinya pernikahan dini.

\section{KESIMPULAN}

Kesimpulan yang dapat di ambil dari hasil penelitian yang dilakukan pada tanggal Maret 2018 tentang faktor - faktor yang menyebabkan terjadinya pernikahan dini adalah :

1. Responden ternyata memiliki pengetahuan yang cukup mengenai pernikahan dan pernikahan dini, namun pernikahan dini tetap terjadi.

2. Pernikahan dini kebanyakan terjadi pada anak yang berusia sekolah dasar atau menengah, dimana selama sekolah tersebut anak belum cukup memiliki informasi tentang pernikahan.

3. Tingkat ekonomi keluarga juga merupakan faktor yang mempengaruhi dan sangat berperan di samping tradisi atau adat istiadat, karena keluarga yang dengan tingkat ekonomi rendah masyarakat sekitar beranggapan bahwa anak yang sudah menikah akan menjadi tanggung jawab suaminya, bukan lagi menjadi tanggung jawab orang tua lagi.

4. Pernikahan dini merupakan sesuatu kejadian yang lazim terjadi di lingkungan masyarakat sekitar dan masyarakat tidak mempermasalahkan hal itu.

\section{SARAN}

1. Bagi Remaja Perempuan

Diharapkan dari hasil penelitian ini dapat menjadikan anggapan untuk menyikapi masalah pernikahan dini, sehingga remaja dapat mengambil keputusan serta menambah pengetahuan remaja terhadap dampak dari pernikahan dini.

2. Bagi Peneliti Lain

Diharapkan dapat menggunakan variabel yang lebih kompleks sehingga dapat mengangkat faktor - faktor lain yang dapat mempeharuhi terjadinya pernikahan dini misalnya media massa juga dapat berperan dalam terjadinya pernikahan dini.

3. Bagi Profesi Kebidanan

Diharapkan hasil penelitian ini dapat memberi manfaat dalam pengembangan profesi kebidanan dalam memberikan pendidikan kesehatan, melalui penyuluhan kepada remaja terkait dengan kesehatan reproduksi remaja yang bertujuan untuk memeberikan pengetahuan mengenai masa reproduksi yang sehat khususnya bagi perempuan, sehingga remaja dapat menghindari terjadinya pernikahan sebelum masa reproduksi sehat. 


\section{DAFTAR PUSTAKA}

Abbas,A.B.I. (2003). Pernikahan Dini. Tanggal 18 Desember 2003, dari http://www. wahdah. or. id/wahdah/indeks: php?options. com content \& do pdf :1\% id. 186.

Ahmad (2009). Pernikahan Dini Masalah Kita Bersama. Tanggal 29 Maret 2010, dari http://pa-bantul net. Diakses 20 Februari $\underline{2018}$

Anonym (2005). Kuatnya Tradisi, Salah Satu Penyebab Pernikahan Dini. dari http ://www.dwword.de/dw/article/0,14897834,00.html.

BPS.2015.Kemajuan yang Tertunda : Analisis Data Perkawinan Usia Anak di Indonesia.

https://www.unicef.org/indonesia/id/Lapo ran_Perkawinan_Usia_Anak.pdf.

BKKBN,2016.Resiko Pernikahan Dini. http://ntb.bkkbn.go.id/_layouts/mobile/disp form.aspx ?List=8c526a76-8b88-44fe-8f81$2085 \mathrm{df} 5 \mathrm{~b} 7 \mathrm{dc} 7 \&$ View $=69 \mathrm{dc} 083 \mathrm{c}-\mathrm{a} 8 \mathrm{aa}-$ 496a-9eb7-b54836a53e40\&ID=678.

Depkes R.I. (2001). Yang perlu diketahui Petugas Kesehatan tentang Kesehatan Reproduksi. Jakarta.

Godam (2008). Devinisi Pernikahan, dari http://www.solexun.net/repository/id/hlth/CR10-Res3ind.pdf

Luthfiyati (2008). Pernikahan Dini Pada Kalangan Remaja (15-19 tahun). Tanggal 24Oktober 2008 dari http://nyna0626blogspot.com/2008/10/Per nikahn-dini-pada-kalangan-remaja15.html

Manuaba.I.B.G (1998). Ilmu Kebidanan Penyakit Kandungan dan Keluarga Berencana untuk pendidikan Bidan.Jakarta.Penerbit Buku Kedokteran EGC.

Meliono, Irmayanti,dkk.(2007).MPKT Modul 1. Jakarta : Lembaga Penerbit FEUI.

Moleong.LJ. (2007). Metode Penelitian Kualitatif. Bandung : Remaja Rosdakarya

Notoatmodjo, S. (2007). Promosi Kesehatan dan Ilmu Perilaku. Jakarta. Rineke Cipta.

Nukman. (2009). Yang Dimaksud Pernikahan Dini. Tanggal 28 Januari 2018, dari http ://www.ilhamuddin.co.cc.

Pohan Nazli Halawani.2017.Faktor yang Berhubungan Dengan Pernikahan Usia Dini Terhadap Remaja Putri. Jurnal Endurance 2 (3) Oktober 2017.
Puspitasari, (2006). Perkawinan Usia Muda: Faktor-Faktor Pendorong dan Dampaknya terhadap Pola Asuh Keluarga (Studi Kasus di Desa Mandalagiri Kecamatan Leuwisari Kabupaten Tasikmalaya). Tanggal 4 Agustus 2011 jam 12.02 WIB dari http://www.solexun.net/repository/id/hlth/CR10-Res3ind.pdf.

Riskesdas (2010).Efek Pernikahan Dini Remaja dan Pengaruhnya bagi Kesehatan. dari http://h3ri.com/efek-pernikahan-diniremaja dan pengaruhnya-bagikesehatan/10502.

Surbakti, 2009.Kenalilah Anak Remaja Anda.Jakarta : PT Elex Media hKomputindo.

Sugiyono. (2008). Metode Penelitian Kuantitatif Kualitatif dan $R \quad \& \quad D$. Bandung : Alfabeta.

Suparyanto (2011) Konsep Pernikahan Dini. http://dr.suparyanto.blogspot.com/2011/0 2/konsep pernikahan dini.html.

Suryati \& Anna (2009). Kesehatan Reproduksi. Yogyakarta : Mulia Medika.

Vinyarviana (2011). Faktor - faktor Penyebab Pernikahan Dini. http://vinyarviana.blogspot.com/2011/03/f aktor-faktor-penyebab-pernikahandini.html

Widyastuti, Y, Rahmawati, A, \& Purnamaningrum. E.Y. (2009). Kesehatan Reproduksi. Yogyakarta : Fitramaya.

, Tujuh Bulan 2017, Angka Pernikahan Dini Masih Tinggi. https://clicksumsel.com/tujuh-bulan-2017angka-pernikahan-dini-masih-tinggi/. .2017.Musi Rawas, Tertinggi Pernikahan Usia Dini. http://www.globalplanet.news/berita/1624/m usi-rawas-tertinggi-pernikahan-usia-din 
